\title{
Design of Flat With Neighborhood Space With Urban Farming Function In Medan
}

\author{
Adela Purba ${ }^{1 *}$, Nelson Siahaan \\ ${ }^{1}$ Department of Architecture, Faculty of Engineering, University of Sumatera Utara, Medan, Indonesia
}

\begin{abstract}
In Medan, flats do not utilize neighborhood space as an urban farming area. In general, flats have a high density of occupants, inflexible designs, and the relationship between one door to another door is relatively close so that communal space is needed. Communal space is a space that functions as a place for social interaction activities for its residents. This flat design has green open spaces such as neighborhood space that can be used as communal spaces both socially and economically productively (urban farming) because flats require both functions. The design approach process used in this design is primary data collection through a field study process and physical data collection that supports scientific and factual data processing. The design analysis was carried out based on the results of literature review and data collection to identify the character of the design area, problems that arise, limitations and potentials, functional requirements, then conduct a review of the regional development plan. This flat is designed using an Ecological Architecture approach to reduce environmental problems in urban areas. The design creates a flat that considers the needs of communal space, green open space, and recreation areas to meet the needs of users. This design can create facilities for the community and become a tourist attraction.
\end{abstract}

Keyword: flats, neighborhood space, urban farming

Received 26 October 2021 | Revised 27 November 2021 | Accepted 27 November 2021

\section{Introduction}

The high population density means that the population rate is high that the land cannot meet the needs, especially for housing needs. One of the efforts needed to improve human quality resources is to improve the housing quality for the community and create a sustainable environment. Flats are built in an environment and divided into functionally structured parts, both horizontally and vertically. Flat is an alternative in accommodating the needs of urban communities that can improve the effectiveness and efficiency of land use, provide green open space in urban areas, overcome slum settlements, safe, and harmonious housing [1]. Flats are the answer to the limited land for settlement in urban areas. The buildings will completely cover the

\footnotetext{
*Corresponding author at: Jl. Perpustakaan, Gedung J7, Departemen Arsitektur, Fakultas Teknik, Universitas Sumatera Utara, Perpustakaan St., J07 Building, Medan, 20155
} 
open space if residences are building with a horizontal system only. Lack of space for water absorption will cause flooding.

Flats are often associated with high occupancy density, inflexible designs, and the relationship between one residential door and another adjacent residential door. In addition, ownership boundaries only cover residential units. Neighboring social behavior in flats can be understood as a way of thinking, feeling, and acting individually because of the presence of neighbors in the vicinity. Individual responses due to neighbors need space to accommodate various response patterns so that these interactions can occur. The space can be used together or called communal space. Communal space is a space that functions as a place for social interaction activities for residents.

Green open spaces in flats need to have a basic concept that accommodates several functions. For example, improving the quality of the environment, meeting the need for outdoor recreation space (outdoor) for residents of flats, providing a space for socialization and togetherness [2].

Neighborhood space is a shared park that can accommodate various activities of several communities. Neighborhood parks can accommodate residents' social activities. The neighborhood spaces have functioned as communal spaces and productive spaces to help fulfill social and food needs. Urban farming is urban farming as an effort to overcome the depletion of agricultural land. The harvest from urban farming is healthier because it fully implements an organic planting system, which does not use chemical fertilizers and synthetic pesticides [3].

The concept of urban farming then offers a solution by creating green open land in dense urban buildings. Urban farming can manage polluted urban areas into a comfortable and healthy environment [4].

In Medan, there are no flats that use the neighboring space as an urban farming area. And also, the neighborhood space is a public space and recreation area that providing facilities to the community and becoming a tourist attraction. Based on all the explanations above, the title of this project is Design Of Flat With Neighborhood Space With Urban Farming Function In Medan.

\section{Literature View}

\subsection{Flats}

Flats are high-rise buildings in an environment divided into functionally structured parts, both horizontally and vertically. Each unit can be owned and used separately, especially for dwellings equipped with shared parts objects and shared lands. Public flats construction is the responsibility of the government, based on 15 paragraph 1 of the Law of the Republic of Indonesia, Number 20 of 2011 concerning Flats [1]. Each high-rise flat building must be planned 
and implemented so that it is strong, sturdy, and stable in the load structure/load combination and meets safety requirements (safety), and meets service requirements (service capability) during the planned service life by considering the function of the building, location, durability, and the possibility of its construction [5]. Flat facilities are commercial facilities, educational facilities, medical facilities, houses of worship, government and public services, and open spaces.

\subsection{Neigboorhood Space}

Neighborhood space is a green open space in the neighborhood of a residential area. The objectives of the procurement and arrangement of green open space in urban areas are maintaining the harmony and balance of environmental ecosystems, realizing a balance between the natural environment and the artificial environment for the benefit of the community, improving the quality of a healthy, beautiful, clean, and comfortable [6]. The proportion of green open space in the city area is at least $30 \%$ of the city area [7].

Neighborhood space is a shared park that can accommodate various activities of several communities in residential and residential areas. Examples of facilities found in neighboring parks are jogging tracks, children's play areas, and areas for gathering. Neighborhood parks can be playgrounds, play yard blocks for preschoolers, and are preferably within walking distance of housing [8].

\subsection{Urban Farming}

Urban Farming combines Green Architecture with agriculture and applies it in urban areas. For small-scale residential, this concept is also known as Home Farming. The concept of Urban Farming also means adjusting the principles of saving energy and caring for the environment. Realizing energy savings can be done by utilizing cross ventilation for air circulation and access to natural lighting. Cross ventilation (also called Wind Effect Ventilation) is a natural method of cooling. Cross ventilation controls the air quality inside of a building environmentally and costeffectively. Cross ventilation can be formed by voids, wide opening dimensions, and the separation between the two building masses. The voids increase building airflow naturally and can be used as a place for urban vertical farming.

The application of Urban Farming in architectural and landscape design is actually beyond green architecture. The function of plants as green elements in buildings does not simply make the microclimate around the building more shady and cool. The plant adds aesthetic and ornament things [9]. In addition, residents can meet their own food needs by utilizing plants that can be consumed, such as vegetables, fruits, and medicinal plants. Urban farming can create a comfortable and healthy environment to live in with various planting systems such as verticulture, hydroponics, and aquaponics that can easily be applied in limited areas [10] - [11]. 


\subsection{Ecological Architecture}

Ecology is defined as the study of the interrelationships between living things and their surrounding environment. Ken Yeang (2006) defines it as: Ecological design, is bioclimatic design, design with the climate of the locality, and low energy design. Emphasizes the integration of local ecological conditions, macro, and microclimates, site conditions, building programs, design concepts and systems that are responsive to climate, low energy use, starting with passive design efforts by considering the shape, configuration, facade, orientation buildings, vegetation, natural ventilation, colors [12].

\section{Methodology}

\subsection{Idea Search}

The design uses a descriptive qualitative method by observing and searching for information directly to the site location to understand the conditions. Descriptive method is a method with an explanation of data based on facts which are then analyzed to produce a conclusion. Then, the data is processed descriptively in writing, pictures, and schematics to conclude from the observations.

\subsection{Method of collecting data}

Several methods for collecting data are literary studies, similar and comparative studies, observation/field surveys, and analytical methods.Results and Discussion

\subsection{Site Location}

The design location is on Jl. Mantri, Brigadier General Katamso, Dalam, Kec. Medan Maimun, Medan City, North Sumatra, 20212 (Figure 1). The design location chosen is a high-density community settlement and a slum area formed along the banks of the Deli River. The site is also close to TOD City. It means close to all public transportation routes such as LRT, BRT, and trains [13]. The total area of the site is $12,300 \mathrm{~m}^{2}$ (Figure 2).

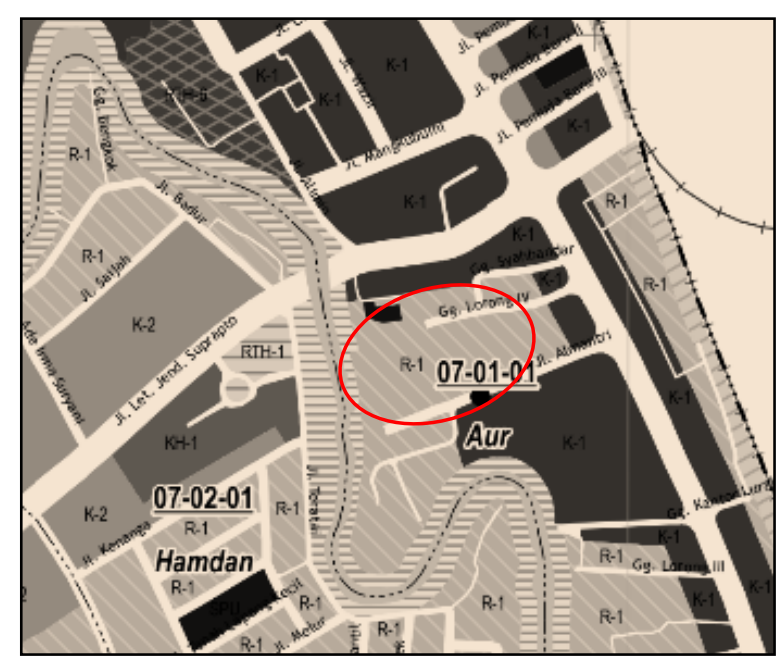

Figure 1 Design Site Location 


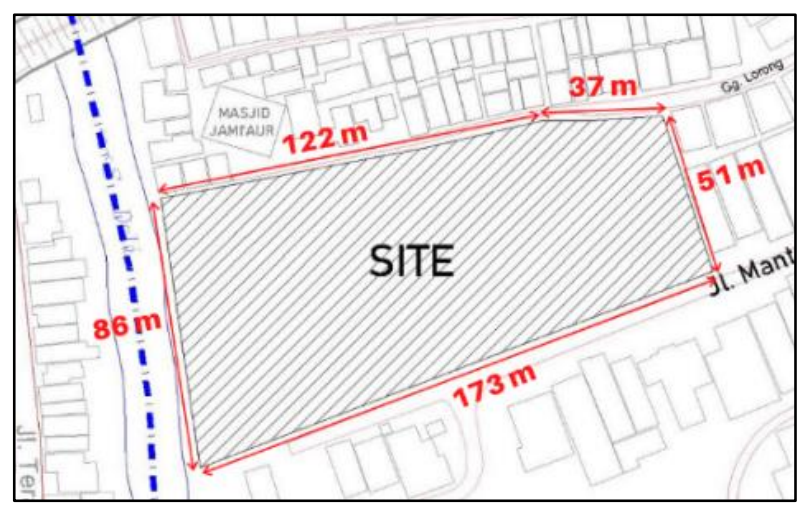

Figure 2 Dimensions or Design Site Size (Source: Personal Data)

\subsection{The Site and Landscape Design Concept}

\section{Zoning}

There are several zones on the site according to its functions and activities (Figure 3). The landscape design includes laying the mass of flats, outdoor areas such as parks, parking, public areas as road areas, and public facilities. The site design and zoning are created based on an ecological approach, the outdoor spaces that accommodate communal functions are on the ground level. As you can see in the figure 4, the building and the landscape are well connected.

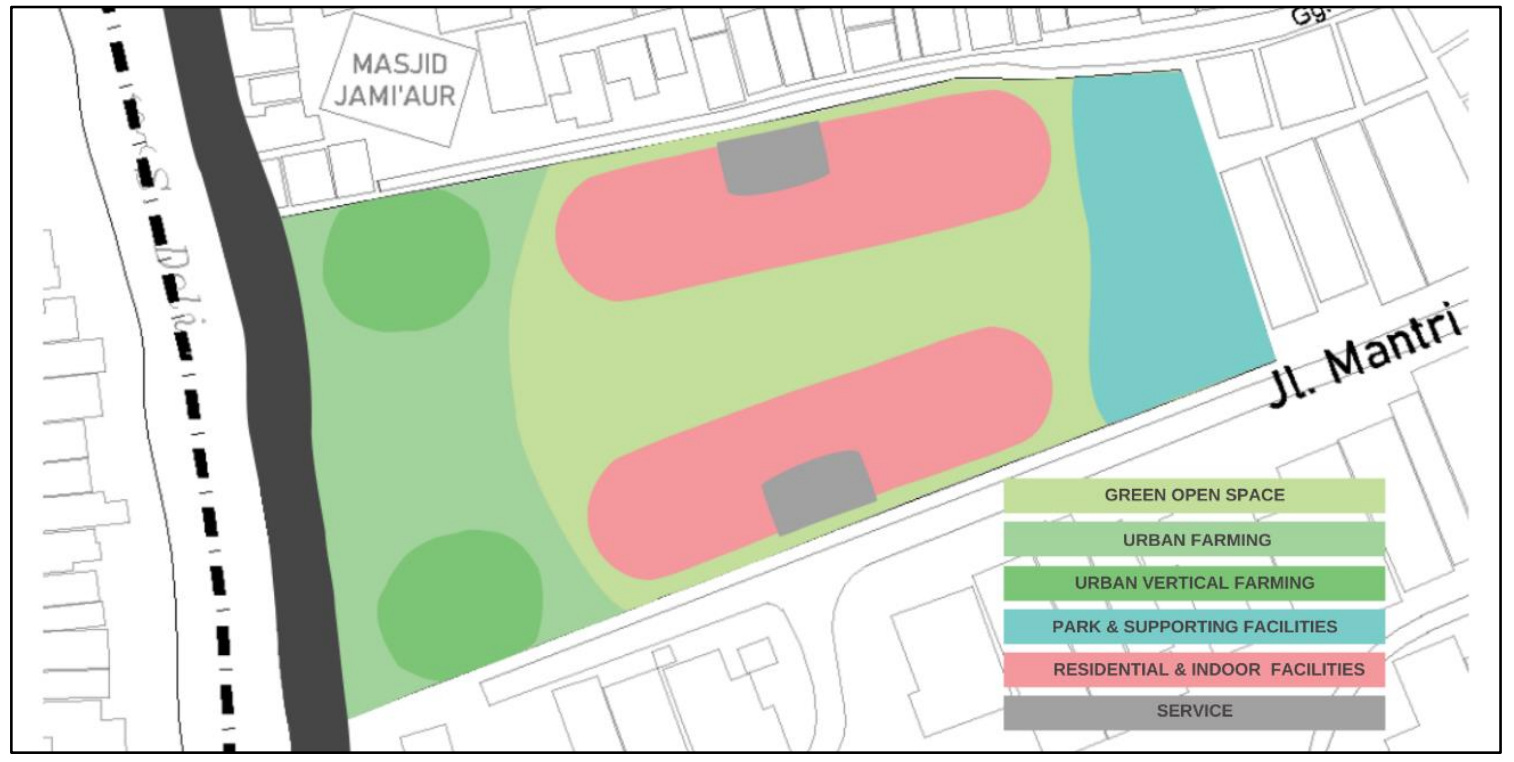

Figure 3 The Concept of Laying Space Zones on the Site

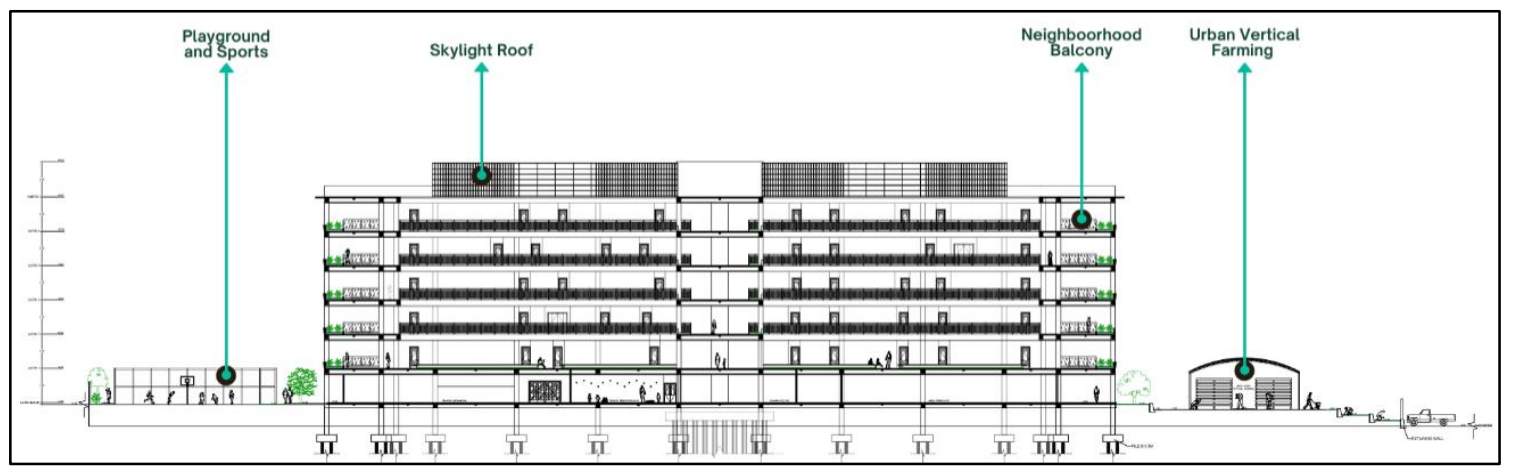

Figure 4 Site section 


\section{Building Mass Laying}

The rectangular shape also affects the space requirements in the building. Rectangles can maximize the need for flat space needs. The layout of the building is parallel to the East-West direction. The building mass design is outside the GSS area with an elongated mass shape. In the Figure 5, there are four building masses. Two building masses are for residential towers and their supporting facilities. The two masses are tower buildings for residential. Two building masses are for urban vertical farming (Figure 5).

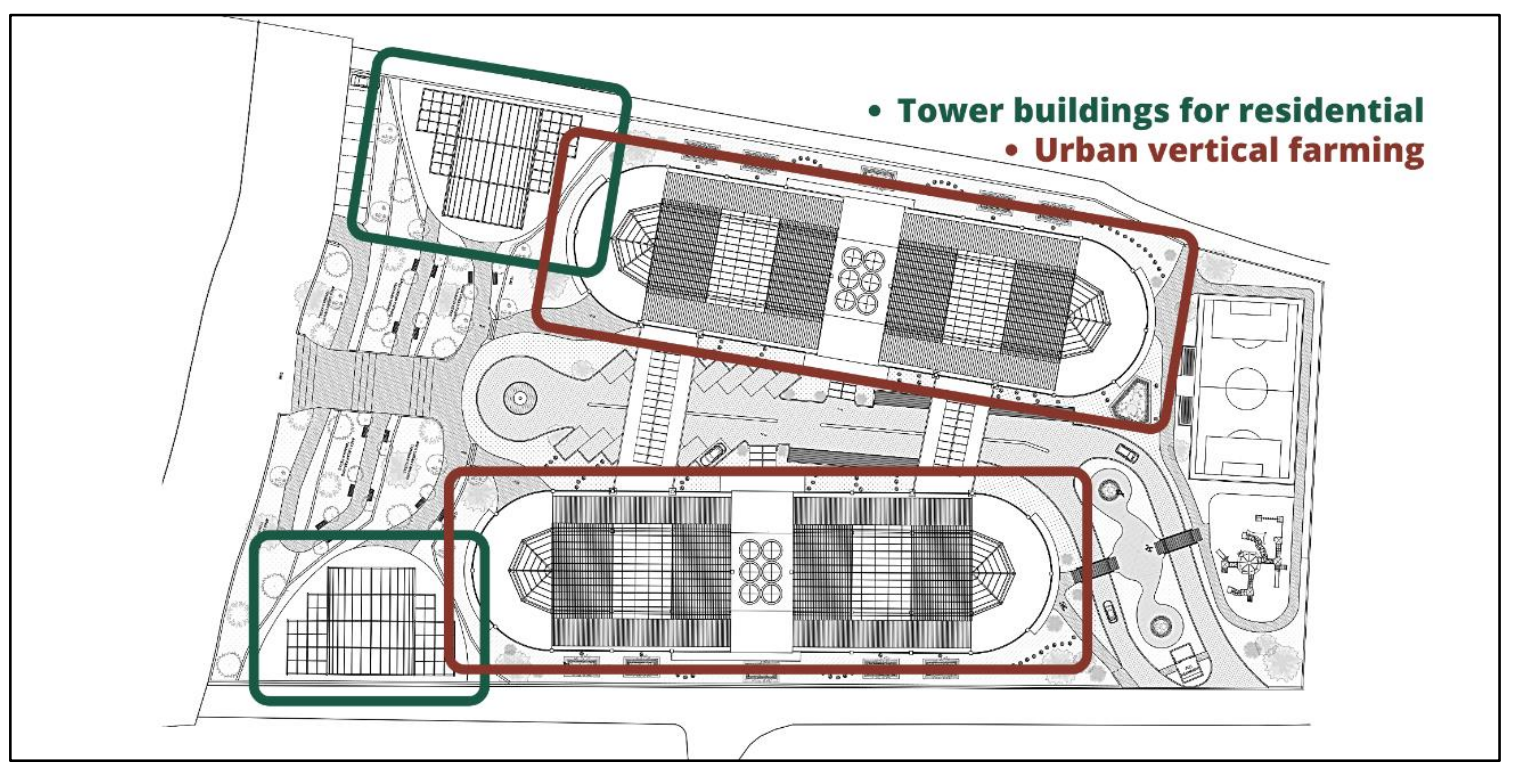

Figure 5 The Concept of Laying Mass on the Site

The building masses are spaced apart and not attached to maximize wind flow from the site to the inside of the building. The orientation of the building is south and north so that less direct sunlight exposes. With this orientation, the building openings are focused on the south and north to maximize natural ventilation in the building with a cross-ventilation system. The circulation path between the two towers connects them, and the health facilities entering the building are on the inside (facing each other). The sky bridge on the 3rd and 5th floors also connects the two towers

\section{Accessibility and Circulation}

The access to the design location is via Jalan Mantri. Jalan Mantri can be accessed via Jalan Brigjend. Katamso (Figure 6). The main circulation path in the site is the center axis of the site and the building masses. 


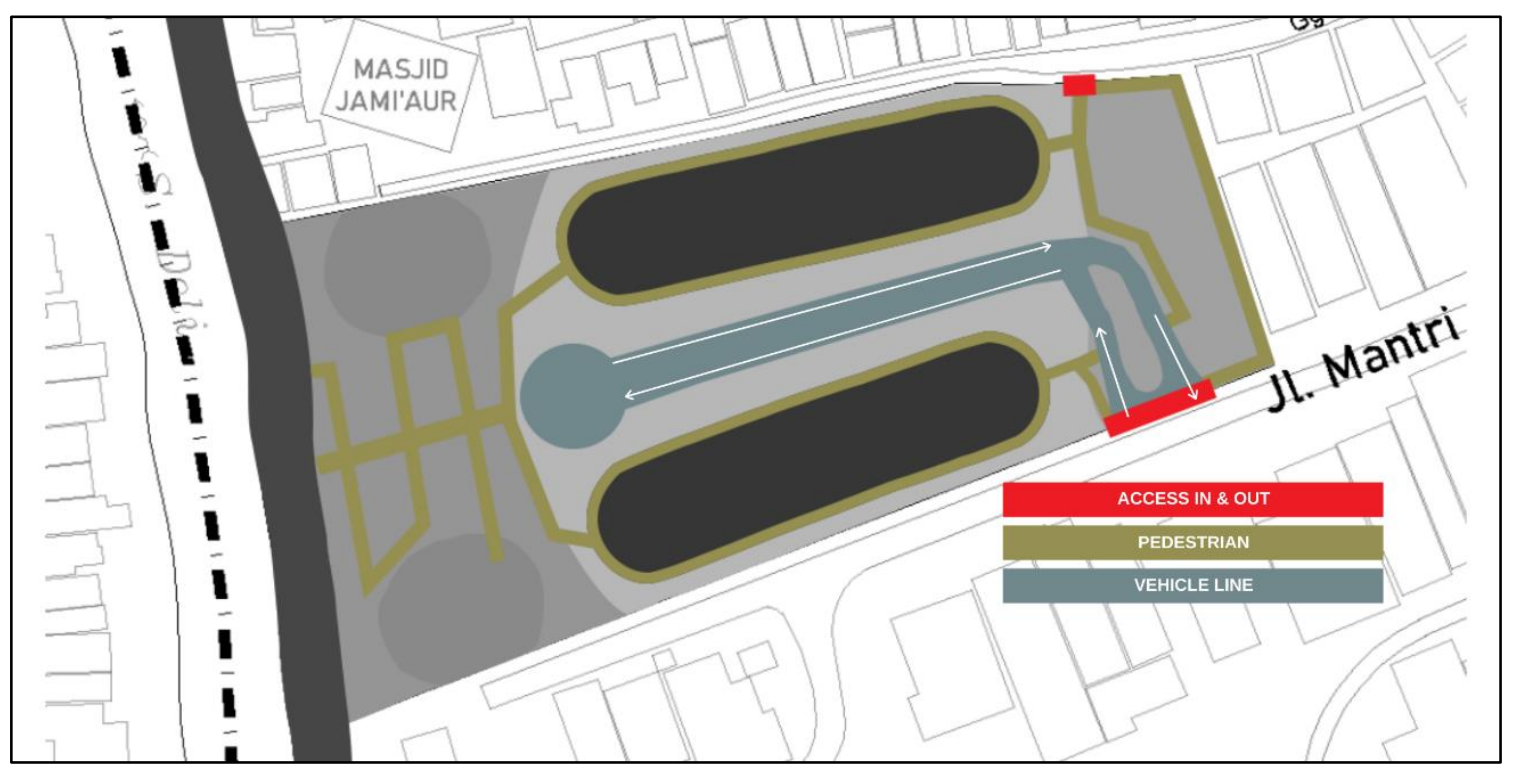

Figure 6 Concept of Accessibility and Circulation on the Site

\section{- Neighborhood Space With Urban Farming Function}

The neighborhood spaces as green open spaces are as much as possible to improve the area's absorption capacity (Figure 7). The landscape design uses the concept of serial vision. Serial vision creates a sequence flow in outer space by presenting a different atmosphere and view at several points in sequence. The use of soil contours on the site can create sequence flow.

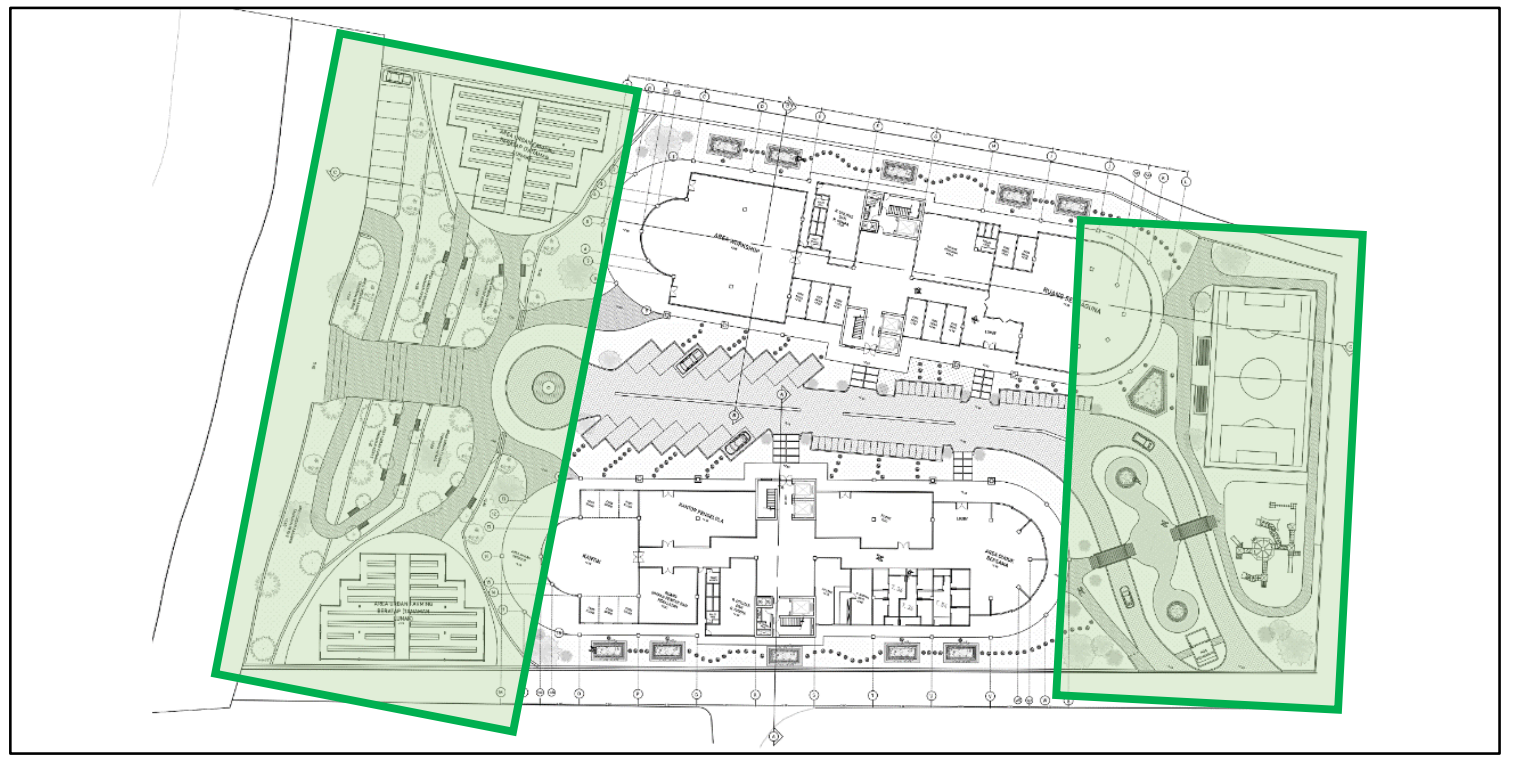

Figure 7 Open Spaces

\subsection{Neighborhood Space}

The health and comfort concept in this design consists of 4 factors. There are Water, Thermal, Lighting, and Waste Management. To maintain a productive green area and reduce air pollution, the neighboring garden in this flat uses the concept of urban farming. Neighborhood parks are sufficient to meet the needs of their residents, both socially and economically. Shady trees and vegetation density make it comfortable and avoid the excessive heat of the sun. The facilities provided are benches and garden lights so that at night the park is not dark. During the day, 
shady plants such as guava trees block sunlight but still give natural light. Garbage facilities have been provided based on the type of waste. The composts from the organic wastes of the residents of this flat are fertilizers for urban farming purposes.

Urban Vertical Farming Area will be planted vertically, for example, celery, lettuce, eggplant, kale, leeks, etc (Figure 8). Verticulture is usually used to grow short-lived crops. Vertical pots for plants that need 8 hours of sunlight are also necessary noticed [14]. Therefore, it is necessary to design vertical farming that still pays attention to sunlight. The sun's rays that are too hot can make the plants wither. Roof protectors are given for hydroponic installations to reduce the sun's rays. The lamp is alternative lighting in places with limited sunlight [15].

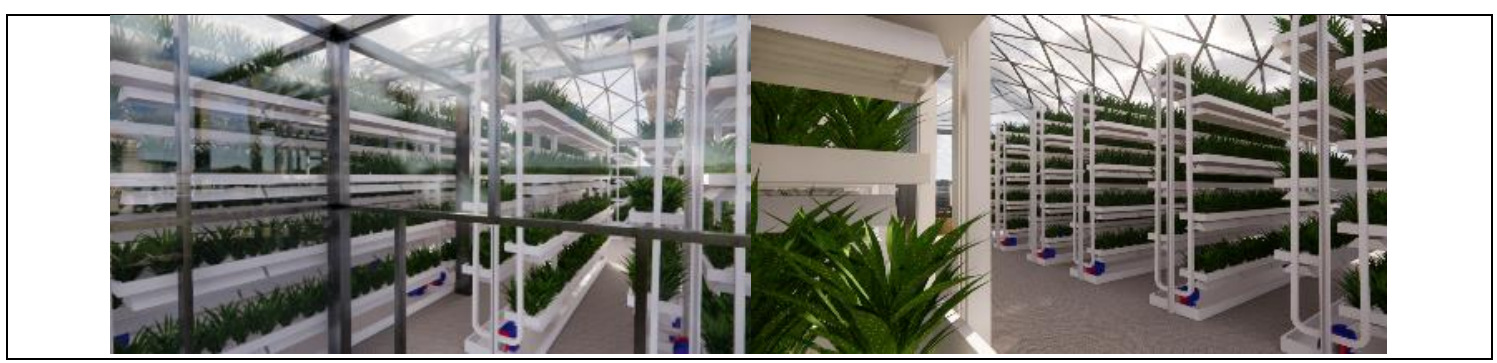

Figure 8 Greenhouse Urban Vertical Farming

Perennials area will be planted with perennials which apart from being productive plants, can serve as a barrier, absorption, and buffer for floodwaters from overflowing rivers. Pedestrian paths and traps in the park are communal spaces, jogging tracks, recreational facilities, and sports (Figure 9).

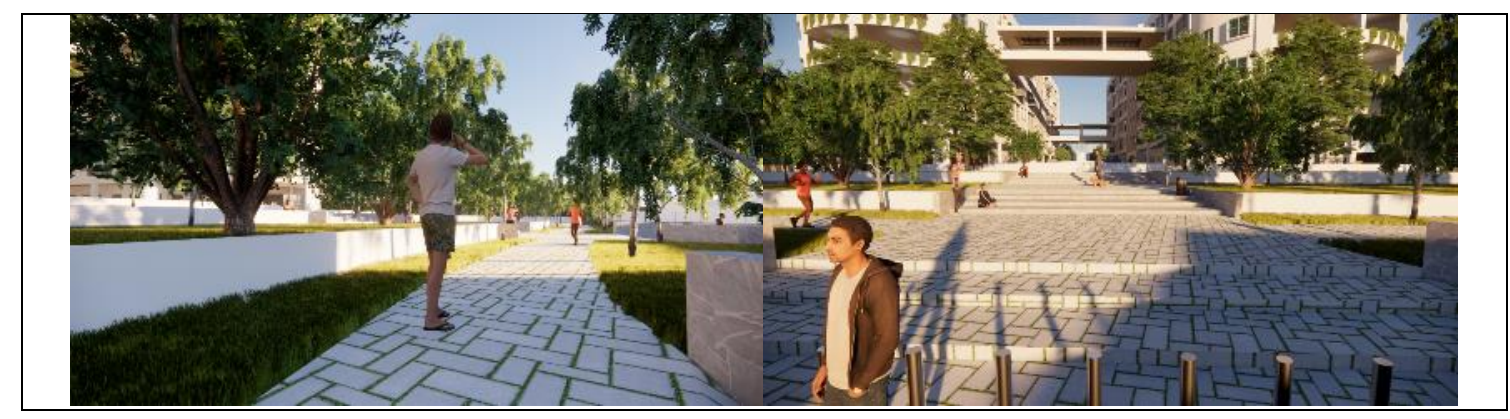

Figure 9 Urban Farming for perennials

Playground and Sports are in front of the first garden found from the main entrance. Playground and sports that can accommodate various activities of the residents of the flats (Figure 10).

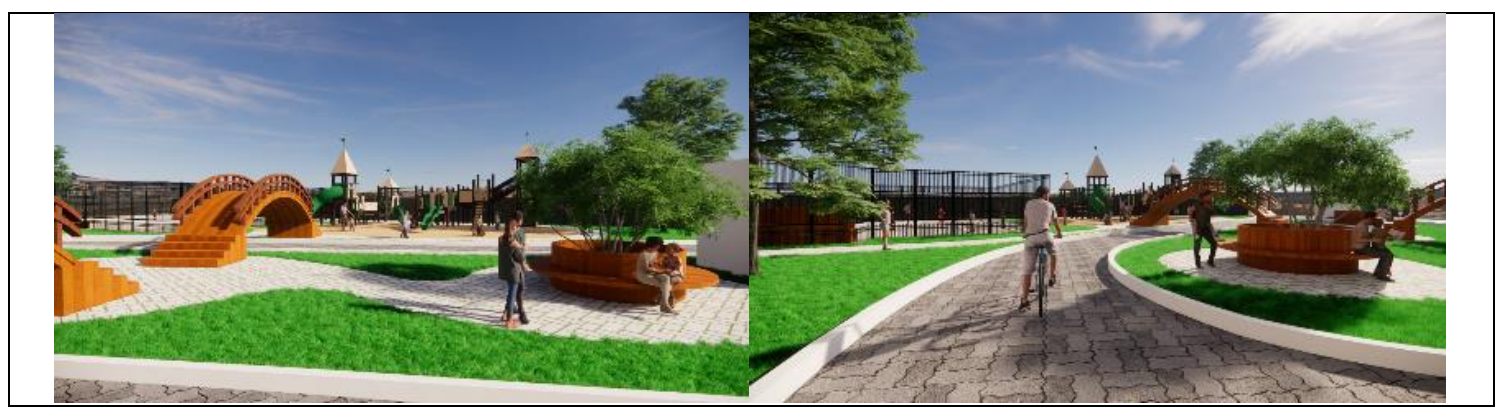

Figure 10 Playground and Sports 
Neighborhood Balconies are shared balconies with a view of the gardens on the site on every floor (Figure 11). The placement of the neighborhood balcony also creates air circulation so that the atmosphere is cool.

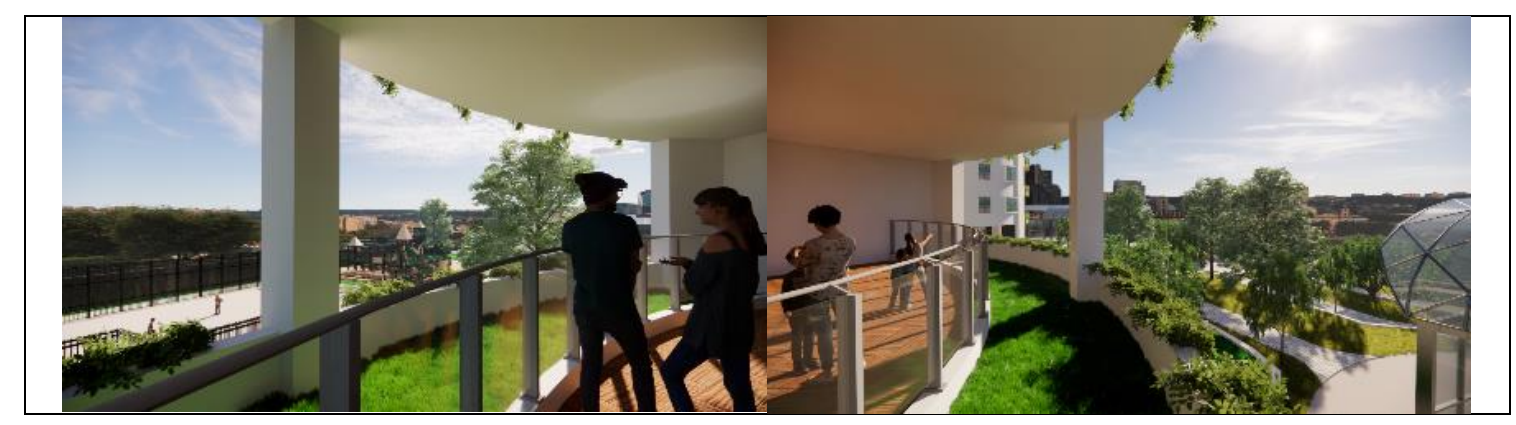

Figure 11 Neighborhood Balcony

\section{Interior Layout Concept}

The design of this flat uses a double-loaded corridor system with voids placed between the two sides of the flat for air circulation in the building. Placing the void area in the middle of the mass will make the void area near each entrance to each flat unit. This flat building has five floors. The ground floor is a public space that accommodates city residents' facilities. Those are outdoor recreation, supporting facilities, such as multipurpose rooms, management offices, information centers, canteens, kiosks, etc. The second floor has a semi-public/semi-private nature, which is a space that is specifically intended for residents of the flats together. The residential units are on the third to fifth floors so that there are clear boundaries between public and private areas.

Inner court and voids (Figure 12) in the building make the space and hallway in residential buildings get excellent lighting because the roof used is a skylight roof (Figure 13). The existence of this inner court is also able to reduce the room temperature. Another function of this inner court can be used as a meeting point or communal space for residents of the flats.

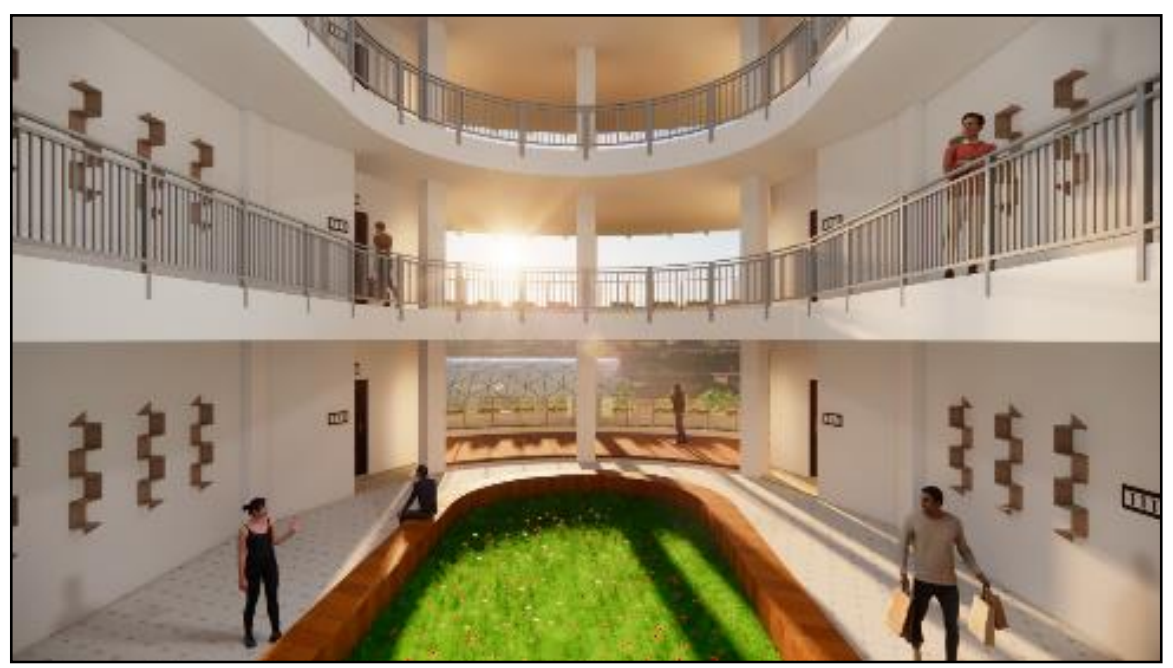

Figure 12 The Void 


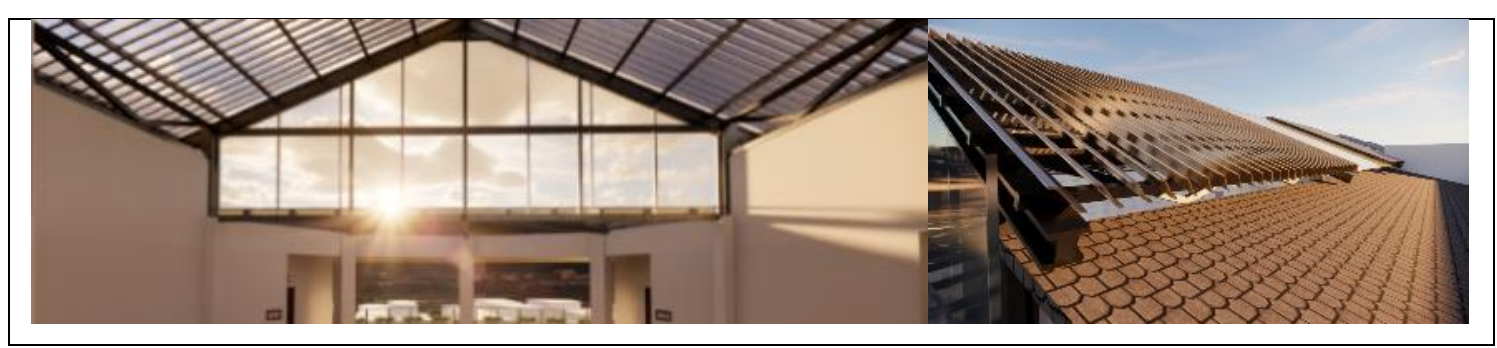

Figure 13 Skylight Roof

\section{Conclusion}

The need for housing in the city of Medan is getting higher in line with the rapid economic growth so that efforts are needed to improve the housing quality for the community and create a sustainable environment. This Flat with Neighborhood Gardens with Urban Farming function is designed with an Ecological Architecture. It creates a harmonious and balanced residential environment. Ecological architecture is applied to the design of exterior and interior spaces. Therefore, an approach that can respond to environmental problems in urban areas is needed by maximizing the green spaces and applying natural lighting and cross ventilation in the building. So that it is comfortable outside and inside the building.

In addition to residential needs, the design of the neighboring garden as a comfortable and functional communal space helps residents from a social and economic perspective. Economically, this flat designed for farming allows its residents to do household-scale gardening and help with household budgets. Other productive economic activities such as trading, workshops, and others are also facilitated and supported in this design. This design is not only a building but a complex design on the site. This design presents the architectural concept of vertical housing (flats) with urban farming using vertical planting techniques.

\section{Acknowledgment}

This research is a study on the design of Flat With Neighborhood Space With Urban Farming Function In Medan with Ecology Architecture Approach, which is expected to be a recommendation for the city government in implementing universal access and environmentally friendly buildings. The author would also like to thank the Department of Architecture, Faculty of Engineering, University of Sumatera Utara, and those who have assisted in this research and design.

\section{REFERENCES}

[1] Undang Undang Republik Indonesia No. 20 tahun 2011, Rumah Susun., 2011.

[2] D. Siskayati, "Evaluasi keberadaan dan penggunaan ruang terbuka hijau di lingkungan rumah susun Provinsi DKI Jakarta," Departemen Arsitektur Lanskap Fakultas Pertanian Institut Pertanian Bogor, Bogor, 2009. 
[3] H. Bunayah, "Pertanian Perkotaan (urban farming): Tren Baru Solusi Peningkatan Ketahanan Pangan Keluarga," 2018. [Online]. Available: http://sumsel.litbang.pertanian.go.id/ BPTPSUMSEL/berita-pertanian-perkotaan-urbanfarming-tren-baru-solusi-peningkatan- ketahanan-pangan-keluarga.html. [Accessed: 6 Jan 2021].

[4] Kania, "Mengenal Urban Farming, Konsep Pertanian Kota untuk Masa Depan," Dekoruma, 27 Feb 2019. [Online]. Available: https://www.dekoruma.com/artikel/82123/urbanfarming-konsep-pertanian-kota. Stylist \& Interior Designer. [Accessed: 6 Jan 2021].

[5] Standar Nasional Indonesia, SNI 03-703-2004, Tata Cara Perencanaan Fasilitas Lingkungan Rumah Susun Sederhana.

[6] Permendagri No. 1 Tahun 2007, Peraturan Kementerian Dalam Negeri (Permendagri) tentang Penataan Ruang, Terbuka Hijau Kawasan Perkotaan.

[7] UU RI No. 26 Tahun 2007, Undang-undang (UU) tentang Penataan Ruang..

[8] Gabriella N, "Desain Taman Lingkungan Untuk Kawasan Perumahan Candi Indah," Yogyakarta, 2018.

[9] S. K. Wijaya, “Konsep Urban Farming di Rumah Kebun Mandiri Pangan,” Arsitag, 2015. [Online]. Available: https://www.arsitag.com/article/konsep-urban-farming-di-rumahkebun-mandiri-pangan-ini-bikin-takjub. [Accessed: 13 March 2021].

[10] J. Meilanita, "Konsep Urban Farming di Rumah Kebun Mandiri Pangan Ini Bikin Takjub," Arsitag, 2016. [Online]. Available: https://www.arsitag.com/article/konsep-urban-farmingdi-rumah-kebun-mandiri-pangan-ini-bikin-takjub. [Accessed: 10 April 2021].

[11] Rahmadini, "Urban Farming : Solusi Ketahanan Pangan Rumah Tangga Perkotaan," Provinsi Kepulauan Bangka Belitung, 2020. [Online]. Available: http://pangan.babelprov.go.id/content/urban-farming-solusi-ketahanan-pangan-rumahtangga-perkotaan. [Accessed: 13 March 2021].

[12] K. Yeang, Designing With Nature The Ecological Basis for Architectural Design, 1995.

[13] Pola Rencana LRT \& BRT Kota Medan, Muatan Perda Revisi RTRW Kota Medan, Rencana Tata Ruang dan Wilayah Kota Medan Tahun 2010-2030.

[14] Ditya Raras Vidyani, Albertus Prawata, Michael Isnaeni, "Perancangan Rumah Susun Dengan Konsep Urban Farming Di Jakarta Pusat," 2018. [Online]. Available: https://docplayer.info/53350339-Perancangan-rumah-susun-dengan-konsep-urban-farmingdi-jakarta-pusat.html. [Accessed: 15 April 2021].

[15] I. V. Sandria, "Desain Sarana Vertikultur Hidroponik Sistem Alir Semi Otomatis," Institut Teknologi Sepuluh November, Surabaya, 2017. 